\title{
THE IONOSPHERIC TOP-SIDE SOUNDER
}

$\mathrm{T}$ HE Alouette satellite, containing an ionosonde capable of sounding tho ionosphere from above, was launchod on September 29, 1962. It was designed and built by the Canadian Defence Rosearch Telecommunica. tions Fstablishment and the satellite was put into orbit by the U.S. National Aoronauties and space Administra. tion. Other co-operating institutions include the U.K. Radio Resoarch Station and the U.S. Central Radio Propa. gation Laboratory. The following three articles prosent some early results from the three co-operating institutions.

\section{SOME PRELIMINARY RESULTS OF SOUNDING OF THE TOP SIDE OF THE IONOSPHERE BY RADIO PULSES FROM A SATELLITE}

\author{
BY E. S. WARREN
}

Defence Research Telecommunications Establishment, Defence Research Board, Ottawa, Canada

Most $\mathrm{T}$ of the present knowledge of the ionized upper atmosphere, the ionosphere, has been obtained by examination of radio waves reflected from the bottom of the ionization layor. Except by the incoherent scatter technique the top side of this layer is inaccessible for oxamination by radio waves from the ground, since the waves which ponetrate to these heights are not reflected but continue outward into space. The concept of sounding the top side of the ionosphere using a sounder' in a satellite was an obvious consequence of the ability to launch artificial earth satellites. As long as four years ago the idea was current among ionospherie research groups in the Unitod States, United Kingdom, Germany and Canada. Because radio sounders, using vacuum tubes, are heavy and consume kilowatts of power, it was neces. sary to use solid-state devices in order to produce a sounder suitable for use in a satellite. The first top-side sounder to operate in orbit was launehed at 0605 G.M.T. on Septomber 29,1962 , as part of the Alouette satellite, $1962 \beta \alpha 1$.

The Alouette satellite contains, in addition to the sounder, apparatus for counting cosmic-ray particles (National Research Council, Ottawa), for observing the very-low-frequency radio spectrum, and for monitoring the engineoring performance. A measure of the cosmic noise-levol as a function of frequency is provided by the automatic gain control voltage of the sounder receiver. The sounder data only will be discussed here.

Tho top-side sounder consists of a transmitter, receiver, timing circuits, antennæ, and antenna matching networks $^{1}$. The power radiated during a pulse is of the order of $10 \mathrm{~W}$. Two orthogonal antennæ are used, a 150-ft. dipole, operating at frequencies below $4.5 \mathrm{Mc} / \mathrm{s}$, and a 75 -ft. dipole for the range $4 \cdot 5-11.5 \mathrm{Mc} / \mathrm{s}$. 'Tho sounder is operated on command. Once started, it functions for 10 min, generating thirty transmissions in which the radio

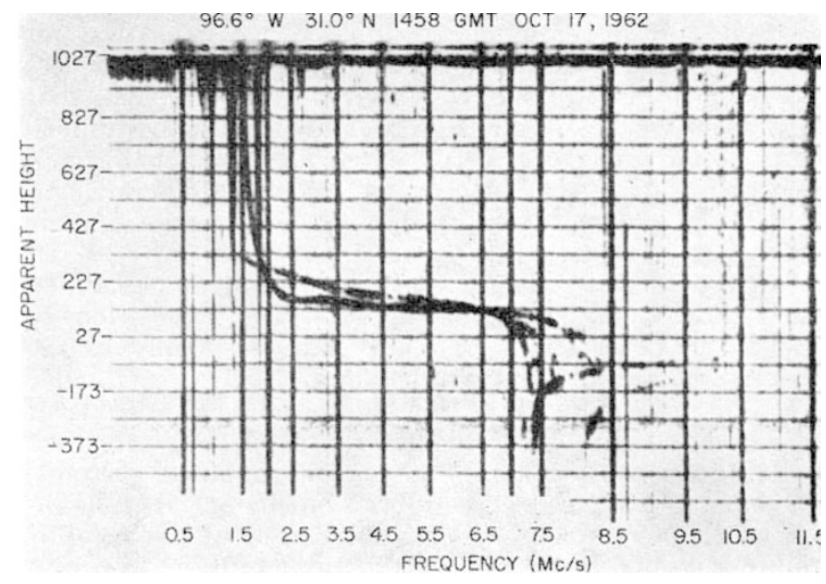

l'ig. 1. A typical top-side ionogram frequency changes linearly with timo over the frequency. band $0.4-11.5 \mathrm{Mc} / \mathrm{s}$. It then shuts off automatically until commanded on again. Nickel-cadmium batterios. recharged by solar cells, permit about $5 \mathrm{~h}$ of operation per day.

Tho Alouette orbital parameters as of Octobor 17, 1962, provided by the National Aeronautics and Spaco Administration Computation Centre, are:

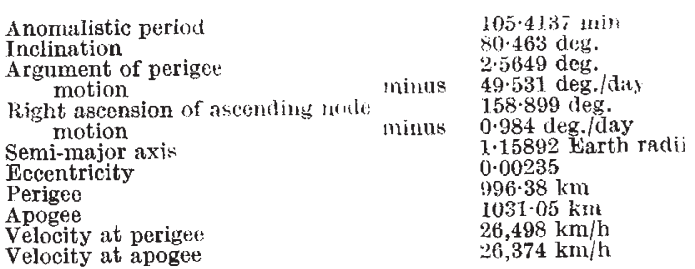

The height of the orbit was ehosen by compromise. The lower the height, the smaller is the region oxplored. 'The greater tho height, the smaller is the signal-to-noise ratio of the signals reflected near the height of the maximum ionization density. The inclination of the orbital

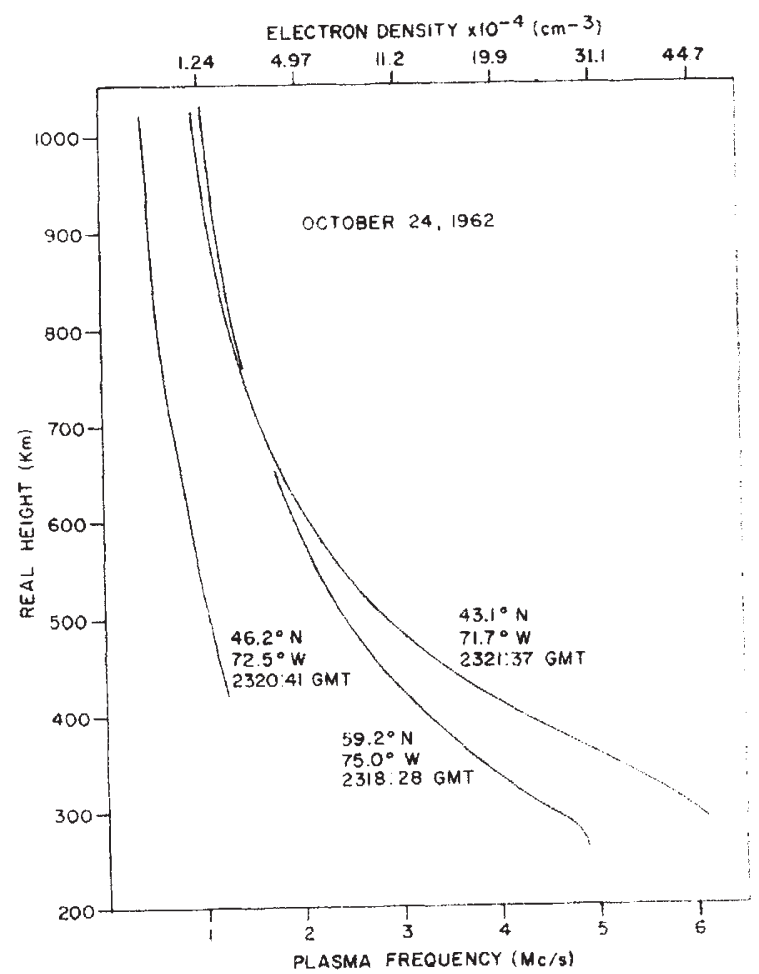

Fig. 2 . Distributions in leight of free electrons showing depression of density at Ottawi latitudes 